\title{
Experiments on Strawberry-Growing in the Central Western Mountainous Region of Puerto Rico ${ }^{1}$
}

\section{T. Singh-Dhaliwal, P. Meléndez González, and A. Torres Sepúlveda ${ }^{2}$ \\ INTRODUC'TION}

The strawberry is a well-known small fruit. It is generally believed that most of its modern cultivated varieties have resulted from hybridization of two American species, Fragaria chiloensis Duchesne, beach strawberry, of the Pacific Coast area, and F. virginiana Duschesne, meadow strawberry, of eastern North America. However, it is possible that some other Fragaria species may have entered into their development $(4,6,8)^{3}$.

The vitamin C-rich and also otherwise nutritive strawberry fruits are much liked as dessert. They are used also for manufacturing preserves, jams, jellies, and so on. Consequently the strawberry has great commercial importance in many areas of the world, particularly those with a temperate or subtropical climate. It is not widely grown in tropical regions. $(5,6)$.

In Puerto Rico there are no commercial strawberry plantings. Only occasionally are strawberries planted in home gardens. At present some farmers are enthusiastic about exploring the possibility of their commercial production.

During the past several years experiments on strawberry-growing have been in progress at Castañer (Adjuntas), located in the middle of the Central Western Mountainous Region of Puerto Rico. The results from these studies on the multiplication of plants, yield and quality of fruits, incidence of diseases and insect pests, and so on, are briefly presented in this paper.

\section{PROCEDURES}

\section{LOCATION OF FIELD AND ITS PREPARATION}

The experiments were carried out on a well-drained and fairly level field, approximately 1,800 feet above sea level. The soil type was Alonso clay with $\mathrm{pH}$ range from 5.91 to 6.30 .

Several weeks before setting the plants the soil was well prepared by digging it to a depth of 9 to 12 inches. Well-rotted cattle manure was

1 This investigation was carried on under the Federal Grant, Research Project Hatch 94, The Introduction, Multiplication, and Evaluation of New Plants for Agricultural and Industrial Purposes, and the Preservation of Valuable Germplasm.

2 Plant Breeder and Research Assistants, respectively, Agricultural Experiment Station, University of Puerto Rico, Río Piedras, P.R. The authors are grateful to several Station personnel for their cooperation during this investigation.

${ }^{3}$ Italic numbers in parentheses refer to Literature Cited, p. $\mathbf{3 5 1 .}$ 
applied at the rate of about 20 tons per acre. The soil was sprayed using 1 to $1 \frac{1}{2}$ liters of aldrin (emulsifiable concentrate containing 2 pounds of technical material per gallon) per 50 gallons of water to control the soilinhabiting insect pests. In experiment 5 , instead of spraying with aldrin, the soil was fumigated with methyl bromide, Dofume MC-2, at the rate of 1 pound per 500 square feet.

All weeds were cut close to the ground to a distance of about 10 feet around the experimental plots so that the strawberry insect pests might not hide and multiply there. Whenever weeds grew taller in the surroundings cutworms appeared in the strawberry plantings. The trees growing near the experimental plots were either removed or severely pruned so that the plots were not shaded.

\section{PLANTING MATERIAL}

Four strawberry varieties, Florida Ninety, Missionary, Klonmore, and Blakemore, adapted to Southern United States, were selected for the present study. Virus-free plants of each of these varieties were obtained from W. F. Allen Co., Salisbury, Md.

The performance of a large number of strawberry hybrids supplied by Dr. Leon Fredric Hough, Professor and Research Specialist, Department of Horticulture, New Jersey Agricultural Experiment Station, New Brunswick, N. J., were observed under field conditions. One of the hybrid seedlings, Florida Ninety $x$ Pocahontas, appeared to be quite vigorous and fruitful. Therefore, it was vegetatively multiplied and tested in comparison with the above-mentioned varieties. In this paper it is referred to as " $\mathrm{Hy}$ brid."

The roots of the plants taken from the nursery were trimmed to a length of 5 to 6 inches. Not more than three young leaves were left on each plant and the others were cut off leaving about 3 inches of petioles. The plants were kept covered with moist burlap. They were planted, keeping the bud and the crown just above ground and soil well-firmed about the roots.

ESTABLISHMENT OF EXPERIMENTS

\section{Experiment No. 1}

The planting of experiment 1 was made in April 1960. Four varieties, Florida Ninety, Missionary, Klonmore, and Blakemore were included. The plants were obtained from Maryland in a dormant condition.

A randomized-block design with five replications was used. Three-feetwide beds, separated by ditches 1 foot wide and 6 to 9 inches deep, were prepared. Each plot, comprising a 20-feet-long and 3-feet-wide bed with ditches on both sides along its length had an area of 80 square feet. Twenty plants were set 1 foot apart in a single row in the center of each bed. 
Soon after planting, the plants produeed some flowers which were removed. From May to September 1960 they produced numerous rumner plants (figs. 1, 2). In October 1960 the planting was thinned, keeping the plants 9 to 12 inches apart. The crop was harvested from December 1960 to June 1961. In July 1961 the experiment was terminated.

\section{Experiment No. 2}

The planting of experiment 2 was made in October 1960. Five varieties, Florida Ninety, Missionary, Klommore, Blakemore, and Hybrid were planted. The plants of the first four varieties were obtained from plots of

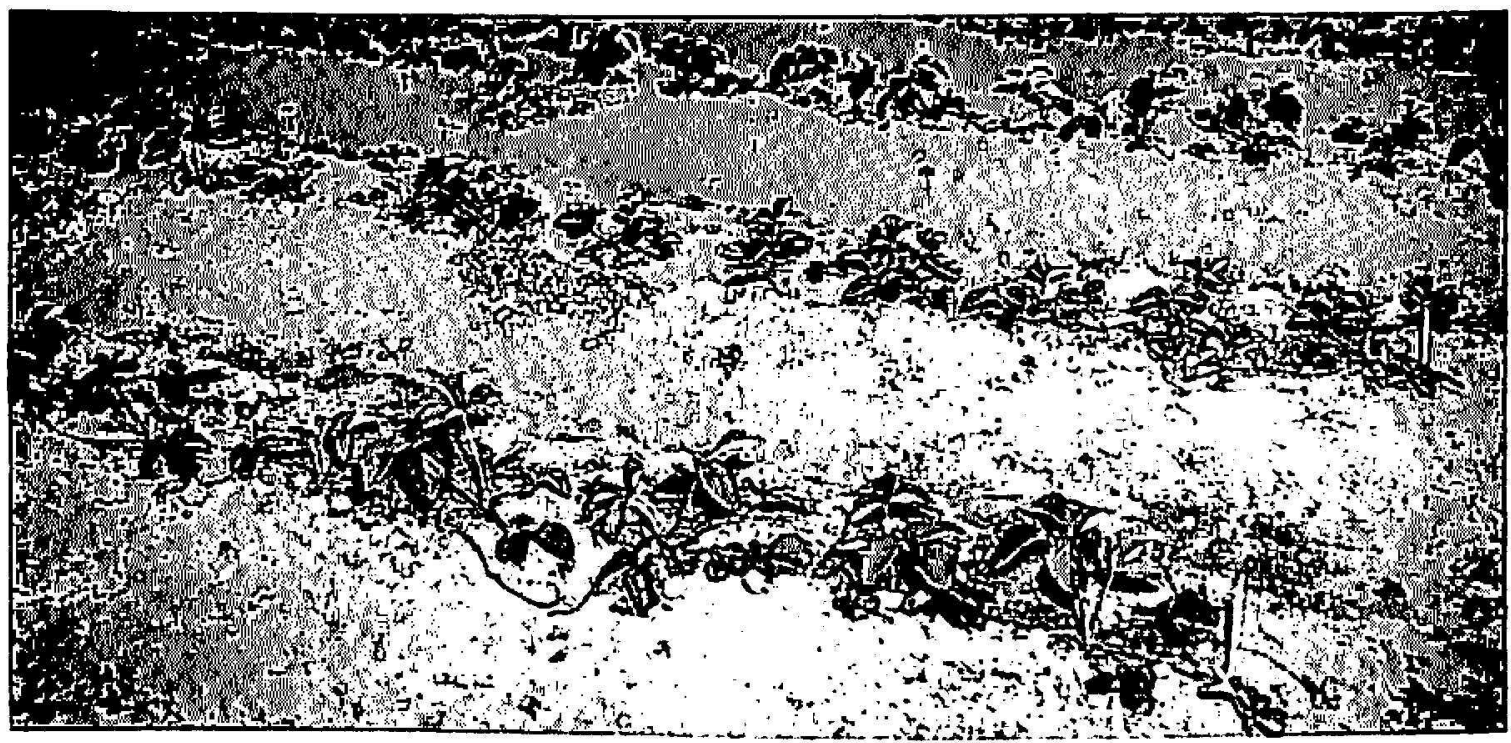

Fia. 1.-Strawberry nursery in April, about a month after setting. The plants have just started to produce runners.

experiment 1, when thinning was carried on. The plants of Hybrid were multiplied in an adjoining field.

A randomized-block design with four replications was used. Beds 4 feet wide, separated by ditches 1 foot wide and 6 to 9 inches deep, were prepared. Each plot, comprising a bed 18 feet long and 4 feet wide, with ditches along both sides of its length, had an area of 90 square feet.

Seventy-two plants were placed in four rows in each bed. The distance from row to row and plant to plant within the rows was 1 foot.

The first crop was harvested from lebruary to June 1961. The planting was renewed in July 1961. The tops of the plants were cut and thrown away from the field, as some of the varieties were severely affected by the common leaf spot disease. Well-rotted cattle manure was applied at the rate of about 20 tons per acre. The other cultural practices were performed as usual. The second crop was harvested from December 1961 to June 1962. The experiment was terminated in July 1962. 
Experiment No. 3

The planting of experiment 3 was made in October 1960. Two varieties, Florida Ninety and Missionary, were included. The plants were obtained from the plots of experiment 1 , when thimning was carried on.

A paired-plot design with four replications was used. Beds 2 feet wide, separated by ditches 1 foot wide and 6 to 9 inches deep, were prepared. Each plot, comprising a bed 18 feet long and 2 feet wide, with ditches along both sides of its length, had an area of 54 square feet.

Thirty-six plants were planted in two rows in each bed. The distance

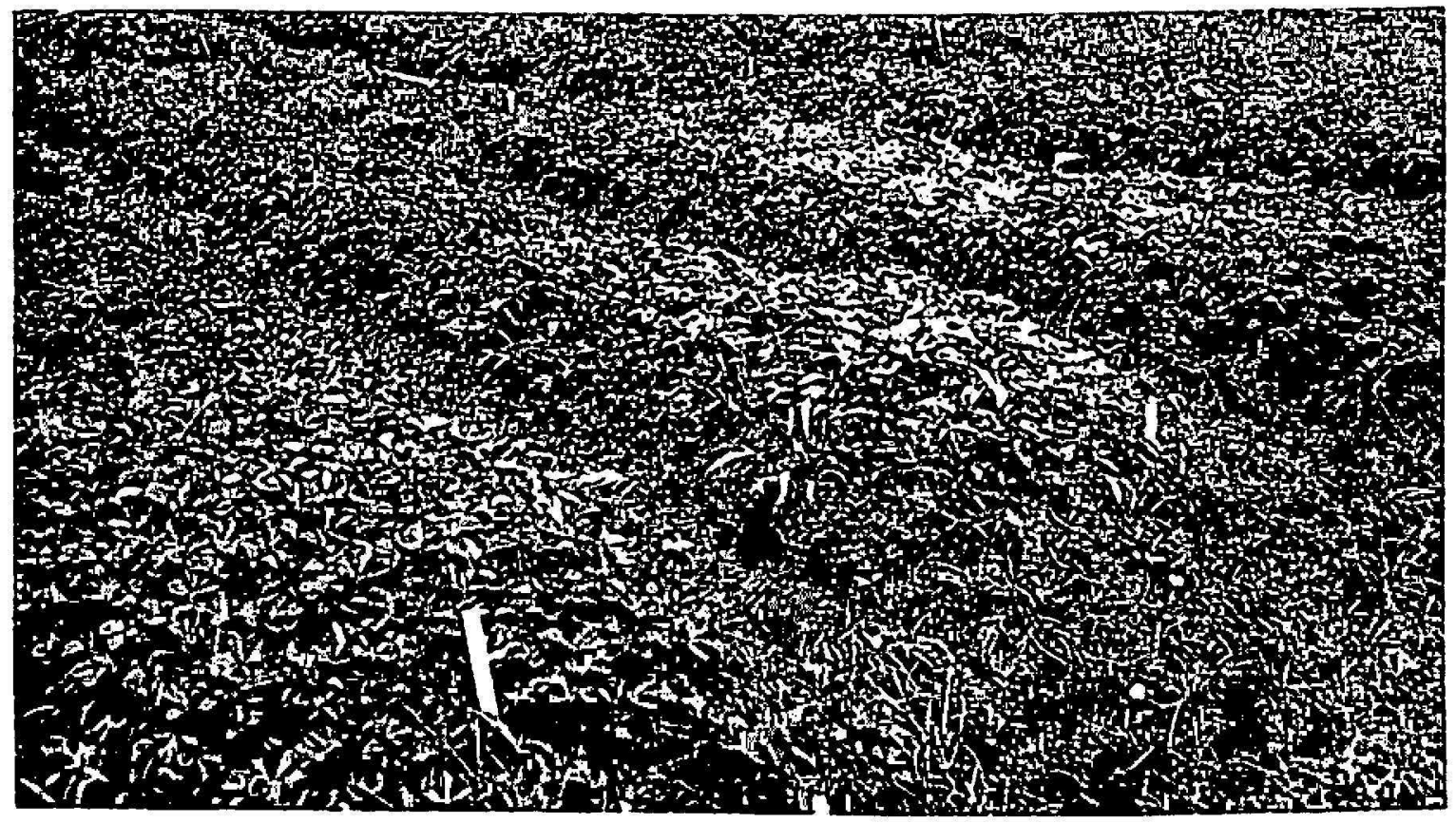

Fig. 2.-Strawberry nursery in September, about 6 months after setting. Numerous runner plants have developed.

between the rows and the plants within the rows was 1 foot. The erop was harvested from February to June 1961. In July 1961 the experiment was terminated.

\section{E.tperimenl No. 4}

The planting of experiment 4 was made in September 1961. Four varieties, Florida Ninety, Missionary, Klonmore, and Blakemore, were included. The plants were obtained from the plots of experiment 2, the runner plants growing between the rows were used.

A randomized-block design with four replications was used. Beds 4 feet wide, separated by ditches 1 foot wide and 6 to 9 inches deep, were prepared. Each plot, comprising a bed 32 fect long and 4 feet wide, with ditches along both sides of its length, had an area of 160 square feet. 
One hundred and sixty plants were placed in four rows in each bed. The rows were 1 foot apart and the distance from plant to plant within the rows was 9 to 10 inches.

The crop was harvested from December 1961 to June 1962. The experiment was terminated in July 1962. In this experiment the plants were severely damaged by cutworms; therefore, it was decided to use the data only for estimating per-acre fruit yields from the varieties included. Analysis of variance was not considered necessary.

Experiment No. 5

The planting of experiment 5 was made in November 1961. Three varieties, Florida Ninety, Missionary, and Blakemore, were included. The plants were obtained from Maryland in a dormant condition.

A randomized-block design with four replications was used. Beds 52 inches wide, separated by ditches 8 inches wide and 4 to 6 inches deep, were prepared. Each plot, comprising a bed 17 feet long and 52 inches wide, with ditches along both sides of its length, had an area of 85 square feet.

Fifty-one plants were planted in three rows on each bed. The rows were $11 / 2$ feet apart and the distance from plant to plant within the rows was 1 foot. The crop was harvested from December 1961 to June 1962. The experiment was terminated in July 1962.

\section{GENERAL CULTURAL PRACTICES}

Soon after planting the plots were irrigated, using an overhead sprinkling system. Later on, if there was no rain, they were irrigated every 5 to 6 days. To the plots of experiment 3 thin black polyethylene plastic mulch was applied at the time of setting the plants.

During the first several months the use of plastic mulch seemed to be very beneficial, as the plants grew vigorously. The fruits also remained clean. However, during dry periods it was difficult to moisten the soil well under the plastic through sprinkling irrigation. Also cutworms and many other types of insects hid under the plastic. Consequently, the plastic was not considered very useful.

The plots of the other experiments were not mulched. Weeds were removed frequently to keep the plantings clean. The field was treated with well-rotted farmyard manure before setting out the plants; therefore, chemical fertilizers were applied only occasionally when some of the plants displayed nutritional deficiencies. Then the plants were sprayed, using $3 / 4$ pound to 2 pounds of Nutrilieaf ${ }^{4}$ per 50 gallons of water. Occasionally 4-4-8 fertilizer was applied at the rate of $1 / 3$ ounce per plant.

4 Mention here does not imply endorsement. 
Diseases and insect pests were carcfully observed and identified as far as possible. Steps were taken to control them.

\section{DATA AND OBSERVATIONS}

The experimental plots were observed as to general plant vigor and runner production. Data on runner production were collected from experiment 1 . Usually the crop was harvested twice a week. The varieties were compared as to size, shape, color, firmness, and taste of ripe fruits. Fruit samples were studied as to longevity and utilization.

\section{RESULTS}

\section{RUNNER PLANTS}

In November 1960, in the planting of experiment 1, the mean numbers of runner plants per square foot of bed of Florida Ninety, Missionary, Klonmore, and Blakemore, were $28.4,21.2,7.8$, and 28.0 respectively. The least significant difference between the means at the 5 -percent level was 6.43 . Evidently Florida Ninety and Blakemore differed very little, but produced more runner plants than Missionary. All these three varieties proved to be markedly superior to Klonmore in capacity to produce runners.

The runner plants from each originally planted plant covered 3 square feet of bed. Thus the multiplication was 23.4- to 85.2-fold.

The runner plants were quite healthy and vigorous. They were well suited for fall setting in experiment 2 . This study indicated that planting material for fall setting can be multiplied locally by establishing spring nurseries using dormant plants obtained from northern parts of the United States (figs. 1, 2).

\section{FRUIT YIELDS}

Fruits were harvested from all the five experiments from 1960 to 1962. The data are summarized in tables 1 and 2 . In experiment 1, Florida Ninety gave the highest yield, followed by Missionary, Blakemore, and Klonmore.

In experiment 2, in the 1961 crop, Missionary gave the highest yield followed by Klonmore, Florida Ninety, Blakemore, and Hybrid. In the 1962 crop of this experiment Florida Ninety gave the highest yield followed by Missionary, Blakemore, Klonmore, and Hybrid. Comparison of yields in both of these crop years indicates that during the second year Florida Ninety and Hybrid gave slightly higher yields, whereas the other varieties yielded much less than in the first year.

To obtain the second-year crop the planting had to be maintained for a relatively longer time, incurring additional expenditures. These results suggest that it may be advisable to harvest only the first-year crop and then destroy the planting. 
In experiment 3 Missionary outyiclded Florida Ninety. The lower yield from Florida Ninety appeared to occur partly because of the fact that, during lengthy dry periods, a relatively larger number of its plants wilted and died.

In experiment 4 Missionary gave the highest yield, followed by Florida Ninety, Klonmore, and Blakemore.

TABLE 1.-Average fruil yields (ounces per plot) in strawberry experiments with 5 varieties at Castañer, P.R., 1960-62

\begin{tabular}{|c|c|c|c|c|c|c|}
\hline Variety & $\begin{array}{c}\text { Expt. 1, } \\
\text { Dec. 1960 } \\
\text { to June } \\
1961\end{array}$ & $\begin{array}{l}\text { Expt. 2, } \\
\text { Feb. to } \\
\text { June 1961 }\end{array}$ & $\begin{array}{c}\text { Expt. } 2 \\
\text { Dec. 1961 } \\
\text { to june } \\
1962\end{array}$ & $\begin{array}{c}\text { Expt. 3, } \\
\text { Feb. to } \\
\text { June } 1961\end{array}$ & $\begin{array}{c}\text { Expt. 4, } \\
\text { Dec. 1961 } \\
\text { to June } \\
1962\end{array}$ & $\begin{array}{l}\text { Expt. 5, Dec. } 1961 \\
\text { to June } 1962\end{array}$ \\
\hline Florida Ninety & 553.20 & 232.50 & 249.75 & 160.50 & 198.75 & 159.50 \\
\hline Missionary & 367.00 & 326.75 & 175.75 & 251.00 & 358.00 & 140.75 \\
\hline Klonmore & 201.20 & 278.50 & 126.50 & - & 120.00 & 一 \\
\hline Blakemore & 311.20 & 180.00 & 131.52 & 一 & 73.50 & 174.50 \\
\hline Hybrid & - & 73.00 & 75.00 & 一 & - & - \\
\hline $\begin{array}{l}\text { Least significant } \\
\text { differences be- } \\
\text { tween varieties at } \\
\text { 5-percent level }\end{array}$ & 130.58 & 56.96 & 79.68 & 66.68 & - & $\begin{array}{l}\text { Differences non- } \\
\text { significant }\end{array}$ \\
\hline
\end{tabular}

1 This experiment was much damaged by eutworms therefore analysis of variance wits considered unnecessary.

T.ıвLE 2.-Estimated per-acre fruil yields (pounds) in strawberry experimets with 5 varieties at Castañer, P. R., 1960-62

\begin{tabular}{|c|c|c|c|c|c|c|}
\hline Variety & $\begin{array}{c}\text { Expt. 1, Dec. } \\
1960 \text { to June } \\
1961\end{array}$ & $\begin{array}{l}\text { Expt. 2, Febs. } \\
\text { to June } 1961\end{array}$ & \begin{tabular}{|} 
Fxpt. 2, Dec. \\
1961 to June \\
1962
\end{tabular} & $\begin{array}{l}\text { Expt. 3, Feb. } \\
\text { to June } 1961\end{array}$ & $\begin{array}{c}\text { Fxpt. 4, Dec. } \\
\text { 1961 to June } \\
1062\end{array}$ & \begin{tabular}{|c} 
Expt. 5, Dec. \\
1961 to June \\
1962
\end{tabular} \\
\hline Florida Nincty & $18,836.46$ & $7,030.80$ & $7,552.44$ & $8,089.20$ & $3,378.75$ & $5,110.38$ \\
\hline Missionary & $12,496.35$ & $9,880.92$ & $5,314.68$ & $12,650.40$ & $6,086 i .00$ & $4,509.63$ \\
\hline Klonmore & $(i, 850.86$ & $8,421.84$ & $3,825.31 i$ & - & $2,040.00$ & 一 \\
\hline Blakemore & $10,596.36$ & $5,443.20$ & $3,969.00$ & - & $1,249.50$ & $5,590.98$ \\
\hline Hybrid & - & $2,207.52$ & $2,268.00$ & - & - & 一 \\
\hline
\end{tabular}

In experiment 5 Blakemore gave the highest yield, followed by Florida Ninety, and Missionary.

Considering all five experiments, Florida Ninety and Missionary appeared to be relatively higher yielders than the other varieties tested. Different planting distances used in experiments 2 to 5 did not seem to influence yield much. However, the plants of different varieties varied in size. Therefore, it seems advisable to consider this factor in deciding on planting distance suited for each variety (table 3). 


\section{FRUITING SEASON}

The strawberry varieties fruited from December to June. Much of the crop was harvested during January to April. The plants set in the field during spring, as in experiment 1 , produced the highest yields, usually during February, whereas those set during fall as in all other experiments produced the highest yields usually during March.

The varieties did not seem to differ much as to percentage of crop produced during different months of the fruiting season, when set in the field about the same time (table 4).

TABLE 3.-Size of individual plants or clumps of 4 different strawberry varieties at Castañer, P.R., at the end of fruiting season in 19621

\begin{tabular}{|c|c|c|c|c|c|c|}
\hline \multirow{2}{*}{ Variety } & \multicolumn{2}{|c|}{$\begin{array}{c}\text { Height? } \\
\text { in inches }\end{array}$} & \multicolumn{2}{|c|}{$\begin{array}{l}\text { Widthr } \\
\text { in inches }\end{array}$} & \multicolumn{2}{|c|}{ Number of crowns } \\
\hline & Range & Mean & Range & Mean & Range & Mean \\
\hline Florida Ninety & $11-13$ & 12.0 & $18-24$ & 21.9 & $7-16$ & 11.5 \\
\hline Missionary & $7-11$ & 9.1 & $15-21$ & 17.9 & $5-44$ & 21.4 \\
\hline Klonmore & $7-12$ & 9.2 & $13-21$ & 16.1 & $3-10$ & 4.9 \\
\hline Blakemore & $7-10$ & 8.9 & $12-20$ & 16.0 & $7-20$ & 12.7 \\
\hline
\end{tabular}

1 A rundom sample of 20 plants or clumps of each variety was studied.

2 Refers to the highest part of the plant or clump.

3 Refers to the maximum width of the plant or clump.

1 Refers only to the crowns arising along the originally set plant, and not the runner plants from it.

\section{FRUIT CHARACTERISTICS}

Florida Ninety produced the heaviest fruits, followed by Hybrid, Missionary, Klonmore, and Blakemore. There was not much variability as to weight of the calices. The varieties showed differences as in the proportion of fruits of different shapes borne by then. A relatively higher proportion of the fruits of Florida Ninety were long conic, those of Missionary, Klonmore and Hybrid, conic, and those of Blakemore, globose conic. Many fruits of Hybrid were misshappen whereas those of other varieties were usually normal.

The fruits of Florida Ninety were much longer than those of the other varieties which did not differ much in this respect (fig. 3).

The varieties did not differ much in color and glossiness of fruit surface, except that the fruits of Hybrid were relatively less glossy. The varieties did not differ in the color of their fruit flesh, except that the fruits of Florida Ninety appeared to have a relatively deep red flesh. The fruits of Blakemore tended to be more firm than those of other varieties. 
The fruits of Florida Ninety and Blakemore were comparatively acid, and those of Missionary and Klonmore were relatively sweet.

The fruits of all the varieties seemed to be fairly aromatic and did not

TABLE 4.-Fruit yields from 5 strawberry varieties in the experimental plantings al Castañer, P.R., in different months of the fruiting season, 1960-62

\begin{tabular}{|c|c|c|c|c|c|c|c|c|}
\hline \multirow{2}{*}{ Expt. No. } & \multirow{2}{*}{ Varicty } & \multicolumn{7}{|c|}{ Percentage of the whole crop produced in- } \\
\hline & & Dec. & Jan. & Feb. & Mar. & Apr. & May & June \\
\hline 1 & $\begin{array}{l}\text { Florida Ninety } \\
\text { Missionary } \\
\text { Klonmore } \\
\text { Blakemore }\end{array}$ & $\begin{array}{l}1.12 \\
2.29 \\
1.30 \\
2.89\end{array}$ & $\begin{array}{r}15.29 \\
14.99 \\
9.17 \\
18.12\end{array}$ & $\begin{array}{l}24.08 \\
26.54 \\
27.02 \\
24.10\end{array}$ & $\begin{array}{l}19.92 \\
26.21 \\
11.57 \\
19.15\end{array}$ & $\begin{array}{l}25.31 \\
21.63 \\
22.13 \\
18.77\end{array}$ & $\mid \begin{array}{r}10.85 \\
7.79 \\
16.55 \\
11.25\end{array}$ & $\begin{array}{r}3.43 \\
.55 \\
12.26 \\
5.72\end{array}$ \\
\hline Entire experiment & & 1.82 & 14.97 & 25.13 & 20.20 & 22.50 & 10.95 & 4.43 \\
\hline 2 & $\begin{array}{l}\text { Florida Ninety } \\
\text { Missionary } \\
\text { Klonmore } \\
\text { Blakemore } \\
\text { Hybrid }\end{array}$ & $\begin{array}{r}0.10 \\
4.13 \\
.40 \\
.38 \\
-\end{array}$ & $\begin{array}{l}19.32 \\
25.32 \\
24.90 \\
15.43 \\
11.00\end{array}$ & $\begin{array}{l}16.82 \\
12.80 \\
12.65 \\
13.14 \\
12.00\end{array}$ & $\begin{array}{r}42.14 \\
37.13 \\
4.71 \\
40.57 \\
39.00\end{array}$ & $\begin{array}{l}15.12 \\
15.65 \\
15.42 \\
14.86 \\
32.33\end{array}$ & $\begin{array}{l}5.11 \\
3.56 \\
3.16 \\
8.00 \\
1.33\end{array}$ & $\begin{array}{l}1.40 \\
1.42 \\
2.77 \\
7.62 \\
4.33\end{array}$ \\
\hline Entire experiment & & 1.12 & 20.15 & 14.08 & 40.16 & 16.95 & 4.55 & 3.00 \\
\hline 4 & $\begin{array}{l}\text { Florida Ninety } \\
\text { Missionary } \\
\text { Klonmore } \\
\text { Blakemore }\end{array}$ & $\begin{array}{l}0.75 \\
.35 \\
- \\
.34\end{array}$ & $\begin{array}{c}3.40 \\
13.62 \\
- \\
3.74\end{array}$ & \begin{tabular}{|r}
29.43 \\
12.43 \\
9.44 \\
16.33
\end{tabular} & $\begin{array}{l}41.26 \\
46.09 \\
45.28 \\
44.90\end{array}$ & $\begin{array}{l}18.62 \\
17.95 \\
28.33 \\
17.69\end{array}$ & $\begin{array}{r}5.41 \\
8.80 \\
10.51 \\
7.14\end{array}$ & $\begin{array}{r}1.13 \\
.77 \\
6.39 \\
9.86\end{array}$ \\
\hline Entire experiment & & 0.42 & 8.09 & 17.15 & 44.53 & 19.40 & 7.91 & 2.50 \\
\hline 5 & $\begin{array}{l}\text { Florida Ninety } \\
\text { Missionary } \\
\text { Blakemore }\end{array}$ & $\begin{array}{l}0.31 \\
1.42 \\
4.58\end{array}$ & \begin{tabular}{|l|}
$22.26 \mathrm{i}$ \\
25.40 \\
19.48
\end{tabular} & $\begin{array}{r}9.40 \\
13.50 \\
7.59\end{array}$ & $\begin{array}{l}42.48 \\
41.74 \\
37.68\end{array}$ & $\begin{array}{l}17.71 \\
12.08 \\
14.76\end{array}$ & $\begin{array}{r}5.49 \\
4.62 \\
10.74\end{array}$ & \begin{tabular}{|l|}
2.35 \\
1.24 \\
5.16
\end{tabular} \\
\hline Entire experiment & & 2.21 & 22.17 & 9.95 & 40.49 & 14.96 & 7.16 & 3.05 \\
\hline $\begin{array}{l}\text { All } 4 \text { experiments com- } \\
\text { bined }\end{array}$ & & 1.46 & 15.61 & 19.43 & 31.50 & 19.82 & 8.59 & 3.59 \\
\hline
\end{tabular}

seem to differ much in this respect. In this region, from December to June, the average maximum temperature usually varies from $79^{\circ}$ to $84^{\circ} \mathrm{F}$. and the average minimum temperature usually varies from $56^{\circ}$ to $62^{\circ} \mathrm{F}$. Therefore, the fruits may not be so aromatic as those produced in much cooler regions (table 5). 


\section{LONGEVITY OF HARVESTED FRUITS}

The strawberry fruits were highly perishable. Fruits harvested when almost ripe, showing some green or white color, kept well at room temperature only for about a day. If, immediately after harvesting, they were stored at $40^{\circ} \%$. they remained in fairly good condition for several days.

\section{UTILIZATION OF FRUITS}

As strawberry fruits are not commonly known in Puerto Rico they were supplied to many persons to collect information on their acceptability. In general, almost everybody liked to eat the fully ripe fresh fruits. However,

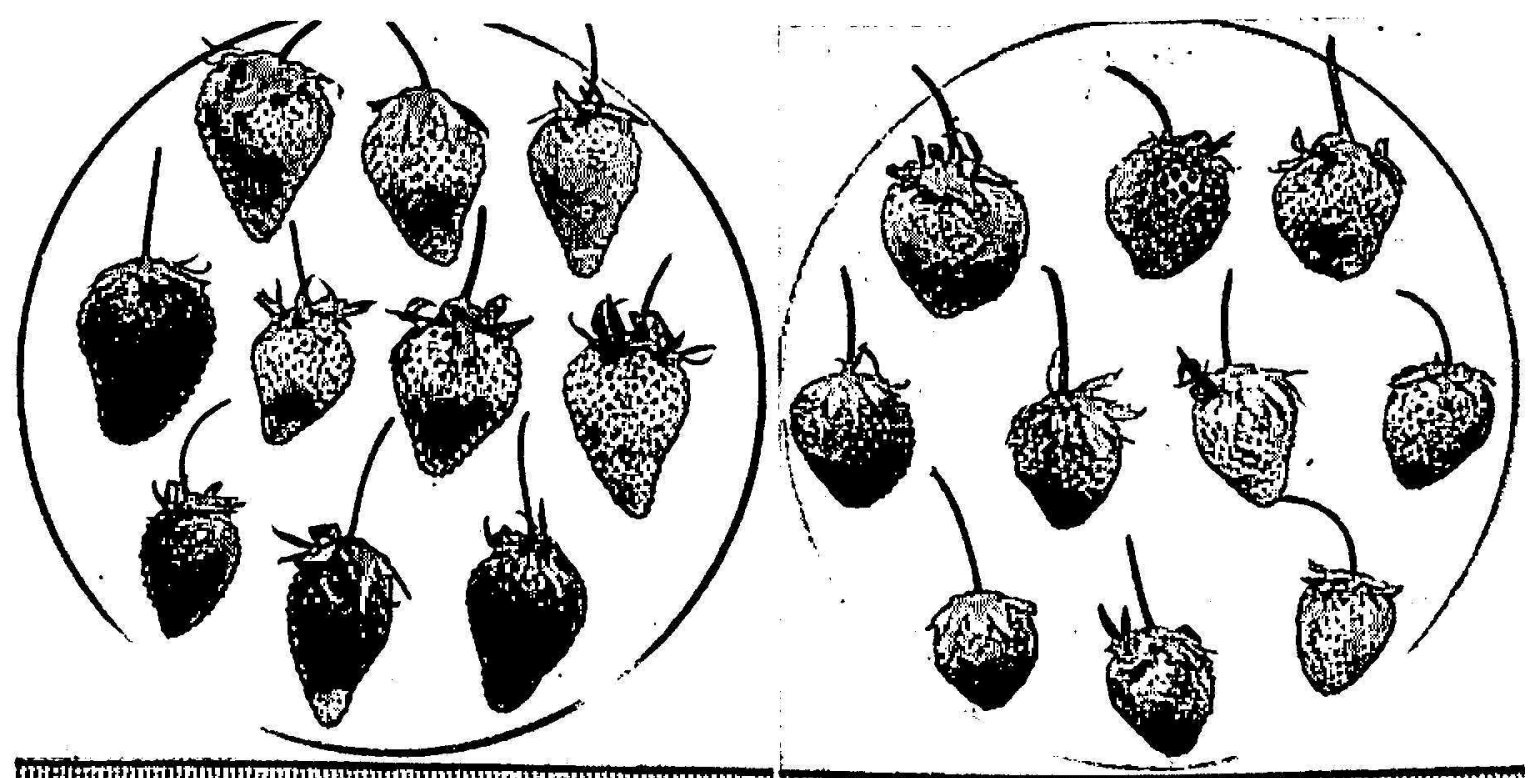

(3)

A

B

Fic, 3.-A, Fully developed fruits of Florida Ninety; B, Fully developed fruits of Missionary.

the fruits could have been used also in many other ways such as for making jams, jellies, and so on.

\section{INSECT PESTS}

The strawberry plants were severely damaged by larvae of cutworms (Agrotis $\mathrm{sp}$ ) on several occasions during July to November. The larvae were controlled by spraying plants and soil surface using.

I)IT (50-percent wettable powder)........... 11/2 to 2 pounds

Parathion (15-pereent wettable powder)......... 1 to 2 pounds

)ieldrin (emulsifiable concentrate containing $1 \frac{1}{2}$ pounds per gallon) ...2 (quarts Water 50 gallons

Applications were made every 8 to 10 days until the insects disappeared. 
From July to November the plants were not fruiting, so there was no problem of insecticide residue. During the fruiting season, that is from December to June, the cutworms did not appear in large numbers. Hence

TABLE 5.-The characteristics of fruits of 5 strawberry varieties grown in the experimental plantings at Castañer, P.R., as studied during May $1961^{1}$

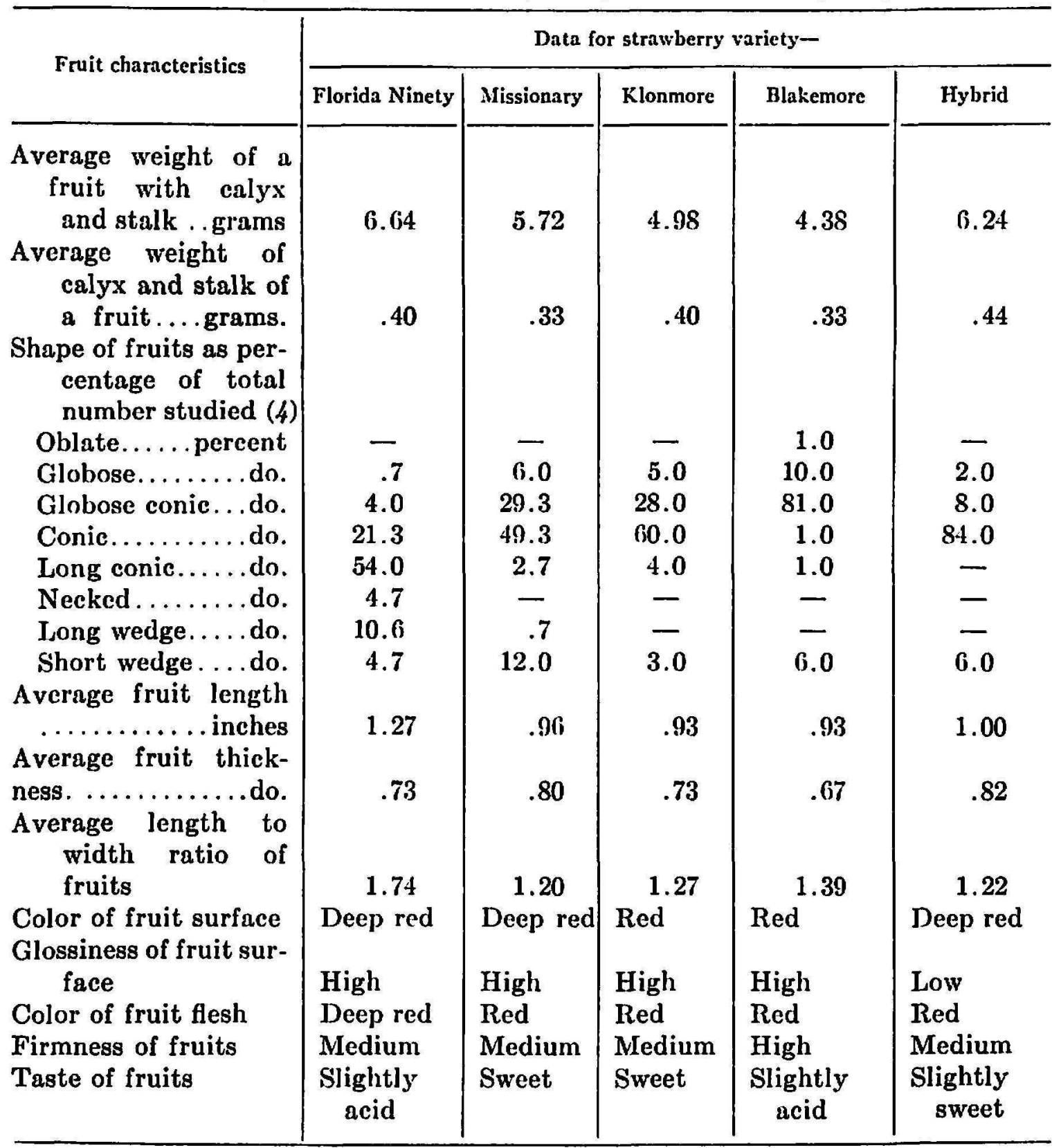

1 Samples comprising 50 to 150 fruits of each variety were studied. Most of these fruits were partly ripe, whereas the others were fully ripe. Only fully ripe fruits were used for comparative study of the latter 5 characteristics.

there was no need of spraying. However, the cutworms may appear in large numbers during this period and then it would be necessary to consider the problem of insecticide residue on the fruits. 
Slugs frequently damaged the fruits. They were controlled by applying small quantities of Buggetta 2 to 3 feet apart twice a month.

The roots of strawberry plants exhibited symptoms of damage from nematodes. Fumigation of soil with methylbromide, Dowfume MC-2, at the rate of 1 pound per 500 square feet of land before planting, seemed to provide some control.

In addition to the above several other insects were observed in the strawberry plantings, but none of them seemed to be causing any serious damage to the crop. However, there is need of continuing the study of insect pests and the methods for their control $(1,2)$. Insecticides are poisonous. Therefore, they should be used with extreme caution following the instructions on the container labels.

\section{DISEASES}

Florida Ninety and Hybrid were severely affected by the common leaf spot disease, caused by the fungus Mycosphaerella fragariae (Tul.) Lindau. The other varieties remained almost free of the disease. Efforts were made to control the disease by spraying the plants, using $3 / 4$ pound to $11 / 2$ pounds of captan (50-percent wettable powder) per 50 gallons of water. As the spraying could be done only at intervals of 3 to 6 weeks, the disease could not be controlled. Probably more frequent sprayings might have controlled the disease.

The leaf-scorch disease, caused by the fungus Diplocarpon carliana (Ell. and Ev.) Wolf., appeared on some leaves of all the varieties. But it was extremely slight and required no control.

None of the varieties showed symptoms of virus diseases. This may be because their planting material was obtained from nurseries certified to be free of virus diseases.

The strawberry crop is affected by many additional diseases in areas where it is raised commercially $(1,7)$. It is possible that, in future, some of these diseases may appear in Puerto Rico. Therefore, study of them should be continued.

\section{POSSIBILITIES OF COMMERCIAL STRAWBERRY PRODUCTION IN PUERTO RICO}

There is considerable demand for strawberry fruits in Puerto Rico. In due course, as more people become acquainted with the uses of this fruit, demand may even increase.

In the experimental plantings, the strawberry varieties Missionary and Florida Ninety gave fairly high yields of good-quality fruit. Fruit yields and quality may be improved by further research on varieties, propagation 
of planting material, application of fertilizers, control of diseases and insect pests, and so on.

The present study indicates that strawberries can be raised in home gardens, and possibly on a commercial scale. However, as the cost of strawberry production seems to be quite high, farmers interested in commercial production should first plant them on a small scale to get the necessary experience in their culture and marketing. Then they will be in a better position to plan commercial production.

\section{SUMMARY}

Experiments on strawberry-growing were carried on for several years at Castañer located in the Central Western Mountainous Region of Puerto Rico. The experimental field had Alonso clay soil with $\mathrm{pH}$ range from 5.91 to 6.30. It was fairly level and well-drained. Its altitude above sea level was approximately 1,800 feet.

The dormant strawberry plants received from Maryland produced numerous runner plants when planted in spring. The multiplication was 23.4 to 85.20 times. The runner plants were quite suited for fall planting.

The strawberry varieties Florida Ninety, Missionary, Klonmore, Blakemore, and Hybrid (Missionary $\mathrm{x}$ Pocahontas) were tested in replicated plots in different field trials. In general the first two varietics gave relatively higher fruit yields.

The strawberry plantings made during spring yielded more than those planted during fall. A strawberry planting made during fall produced a very small crop the second year. Thus renewing strawberry plantings did not seem to be justified.

The strawberry varieties fruited from December to June. Much of the crop was harvested from January to April. The strawberry varieties differed in fruit characteristics. The two high-yielding varieties, Florida Ninety and Missionary, were observed to be producing fruits of good quality. Fruits harvested when almost ripe, and showing only some green or white color, kept well at room temperature for about a day. If, immediately after harvesting, they were stored at $40^{\circ} \mathrm{F}$. they remained in fairly good condition for several days. The fruits had good taste and were much liked for eating fresh.

The strawberry plantings were affected by cutworms (Agrotis sp.), slugs, and nematodes which were controlled by the use of suitable insecticides. Florida Ninety and Hybrid were severely affected by the common leaf spot disease caused by the fungus Mycosphaerella fragariae (Tul.) Lindu. The other varieties remained almost free from the disease.

The present study indicates that the strawberry can be raised in home 
gardens, and possibly on a commercial scale, in the Central Western Mountainous Region of Puerto Rico. However, as its cost of production seems to be quite high, farmers interested in raising it commercially should first plant it on a small scale to get necessary experience in its culture and marketing of fruits.

\section{RESUMEN}

Durante varios años se llevaron a cabo experimentos soble el cultivo de la fresa en Castañer en la Región Central Occidental Montañosa de Puerte Rico. El campo experimental estuvo ubicado en un suelo Alonso arcilloso con un pH de 5.91 a 6.50. El terreno era bastante llano y bien desaguado. $\mathrm{Su}$ altura sobre el nivel del mar era de aproximadamente 1,800 pies.

Las plantas de fresas, en estado de reposo, recibidas de Maryland, se sembraron en la primavera y produjeron numerosos sarmientos. La multiplicación fué de 23.4 a 85.20. Los sarmientos estuvieron disponibles para la siembra en el otoño.

En distintos predios experimentales y en parcelas replicadas se sembraron las variedades Florida Ninety, Missionary, Klonmore, Blakemore y la Híbrida (Missionary $x$ Pocahontas). En general, las dos primeras varicdades relativamente produjeron los mayores rendimientos de fruta.

Las siembras hechas durante la primavera produjeron más que las que se hicieron durante el otoño. Una siembra que se hizo durante el otoño produjo una cosecha muy escasa el segundo año; por lo que no se justifica que se renueven las siembras.

Las variedades de fresas fructificuron de diciembre a junio. La mayor parte de la cosecha se llevó a cabo de enero a abril. Las variedades variaron en cuanto a las características de sus frutas. Se observó que las variedades Florida Ninety y Missionary, las de los mayores rendimientos, produjeron frutas de buena calidad. Las frutas que se cosecharon cuando estaban casi maduras y que tenían algún color verde o blanco se conservaron bien por un día bajo temperatura ambiental. Si se almacenaban inmediatamente después de cosechadas, a una temperatura de $40^{\circ} \mathrm{F}$., permanecían en condiciones relativamente buenas por varios días. Las frutas tenían buen sabor y gustaron mucho al consumirlas frescas.

Los gusanos cortadores (Agrotis sp.), lapas y nemátodos afectaron las siembras de fresas, pero fueron controlados mediante compuestos químicos específicos. Las variedades Florida Ninety e Híbrida fueron afectadas severamente por la enfermedad de la mancha común de la hoja causada por el hongo Mycosphaerella fragariae (Tul.) Lindu. Las otras variedades se conservaron casi libres de esta enfermedad.

Este estudio indica que la fresa puede sembrarse con éxito en huertos domésticos y posiblemente en escala comercial en la región central occi- 
dental montañosa de Puerto Rico. Sin embargo, como los costos de producción suelen ser altos, se recomienda a los agricultores que deseen producir esta fruta en escala comercial empiecen por hacerlo en pequeño hasta que adquieran la suficiente experiencia en cuanto a su mejor y más económico cultivo y mejor sistema de mercadearla.

\section{LITERATURE CITED}

1. Brooks, A. N., and Kelsheimer, E. G., Insects and Diseases Affecting Strawberries B. 629, Univ. Fla., Agr. Expt. Sta., Gainesville Fla. 1961.

2. Campbell, Roy E., and Taylor, E. A., Strawberry Insects. ...... How to Control Them, USDA Farmers B. 2184, June 1962.

3. Darrow, George M., Strawberry Culture South Atlantic and Gulf Const Regions, USDA Farmers B. 1026, Jan. 1963.

4. Darrow, George M., Scott, D. H., and Waldo, George F., Strawberry Varieties in the United States, USDA Farmers B. 1043. Nov. 1958.

5. ESSO Standard Oil S.A. Ltd., Strawberry Cultivation, ESSO Cullivator, 2 (4) 23-30, 1962.

6. Kennard, William C., and Winters, Harold F., Fragaria Hybrids, Some Fruits and Nuts for the Tropics, Agr. Res. Serv., USDA Misc. Pub. 801, 65-7, 1960.

7. McGrew, John R. Strawberry Diseases, USDA Farmers B. 2140, Oct. 1959.

8. Shoemaker, J. S., Strawberry culture, Small-Fruit Culture, Blakiston Co., Phila. delphia, Toronto, 117-219, 1950. 